\title{
Performance of Green Gram (Vigna Radiata L.) as Influenced by Sulphur and Iron Application
}

\author{
Maddila Teja1, Rabindra Kumar'1, V. Gopijagadeeswar Reddy', \\ M. Vikram Sai², M. Sai Kumar²
}

Department of Agronomy, School of Agriculture, Suresh Gyan Vihar University, Jaipur-302 017, Rajasthan, India.

Received: November 2021

Accepted: January 2022

\begin{abstract}
Background: The present study was carried out on "Performance of Green gram as Influenced by Sulphur and Iron Application" to increase the grain quality and helps in synthesis of protein, vitamins, enzymes and flavoured compounds in the plant.

Methods: A field experiment was conducted during kharif season of 2018 at the Crop Research Farm, Department of Agronomy, Suresh Gyanvihar University, Jaipur. To study the influence of sulphur and iron on the performance of green gram. This experiment was done in randomized block design with eight treatments which are replicated thrice. Treatments consists of $\mathrm{T}_{1}$ control, $\mathrm{T}_{2} 1.0 \% \mathrm{FeSO}_{4}$ as foliar spray at $25 \mathrm{DAS}, \mathrm{T}_{3} 25 \mathrm{~kg} \mathrm{~S} \mathrm{ha}^{-1}$ as $\mathrm{ZnSO}_{4}, \mathrm{~T}_{4} 25 \mathrm{~kg} \mathrm{~S}^{-1}$ as SSP, $\mathrm{T}_{5} 25 \mathrm{~kg}^{-1}$ $\mathrm{S} \mathrm{ha}^{-1}$ as $\mathrm{ZnSO}_{4}+1.0 \% \mathrm{FeSO}_{4}$ as foliar spray at $25 \mathrm{DAS}, \mathrm{T}_{6} 25 \mathrm{~kg} \mathrm{~S} \mathrm{ha}^{-1}$ as SSP $+1.0 \% \mathrm{FeSO}_{4}$ as foliar spray at $25 \mathrm{DAS}^{-}$ $\mathrm{T}_{7} 12.5 \mathrm{~kg} \mathrm{~S} \mathrm{ha}^{-1}$ as $\mathrm{ZnSO}_{4}+12.5 \mathrm{~kg} \mathrm{~S} \mathrm{ha}^{-1}$ as SSP and $\mathrm{T}_{8} 12.5 \mathrm{~kg} \mathrm{~S} \mathrm{ha}^{-1}$ as $\mathrm{ZnSO}_{4}+12.5 \mathrm{~kg} \mathrm{~S} \mathrm{ha}^{-1}$ as SSP $+1.0 \% \mathrm{FeSO}_{4}$ as foliar spray at 25 DAS.

Result: The results indicated that application of $12.5 \mathrm{~kg} \mathrm{~S} \mathrm{ha}^{-1}$ as $\mathrm{ZnSO}_{4}+12.5 \mathrm{~kg} \mathrm{~S} \mathrm{ha}^{-1}$ as SSP $+1.0 \% \mathrm{FeSO}$ as foliar spray at 25 DAS is suitable to get higher green gram yield, compared to other treatments.
\end{abstract}

Key words: Growth, Green gram, Iron, Sulphur, Yield.

\section{INTRODUCTION}

Pulses are an important part of profitable agriculture because a large section of population relies on them as they are low priced source of proteins (Usman et al., 2007). The protein from pulses is easily digestible, relatively cheaper and have higher biological values.

India is the largest producer of green gram where it is grown in an area of 40.70 lakh hectares of land with an average production of 19.01 lakh tons (Anonymous 2018). In India, it is mainly grown as kharif crop in the states of Rajasthan, Maharashtra, Karnataka and Andhra Pradesh. Rajasthan is major green gram growing state of India where green gram is grown in an area of 17.19 lakh hectare of land with an average production of 7.42 lakh tons [Directorate of Economics and Statistics, Ministry of Agriculture and Farmers welfare (DAC and FW), Government of India; 2017-18. Sulphur and iron are one of the most important nutrients for all plants and animals. Sulphur is considered as the fourth major nutrient in increasing agricultural crop production after nitrogen, phosphorus and potassium. As being rich source of proteins, green gram needs to be judiciously fertilized with sulphur as this element plays a key role in protein synthesis and chlorophyll development. Sulphur is a constituent of essential amino acids viz., methionine, cysteine and cysteine-the building blocks of protein. Therefore, sulphur fertilization is considered as critical for seed yield and protein synthesis and for improvement in quality of produce in legumes through their enzymatic and metabolic effects (Bhattacharjee et al., 2013). In addition, sulphur is required by the rhizobia bacteria in legumes including green gram for nitrogen fixation. Foliar application of Fe solutions is one of the most widely used methods for correcting Fe deficiency in many crops. This method of application usually circumvents the problems associated with Fe application to the soil. Goos and Johnson (2000) reported that foliar sprays of Fe significantly reduced iron-deficiency chlorosis, while increased seed yield in soybean. Therefore, balanced fertilization of macro and micro nutrients particularly in combination is very important for proper growth, development and high yield production of crop plants including green gram (Sawan et al., 2001).

\section{MATERIALS AND METHODS}

Green gram crop experiment was conducted in kharif season during 2018 on a sandy loam soil having $\mathrm{pH} 8.48$, organic carbon $0.40 \%$, available NPK $\left(28.00,42.00,290.00 \mathrm{~kg} \mathrm{ha}^{-1}\right)$ electrical conductivity (EC) of $0.32 \mathrm{dS} / \mathrm{m}$, at the Crop Research

\footnotetext{
${ }^{*}$ Corresponding author's E-mail: tejamaddila44@gmail.com

${ }^{1}$ Department of Agronomy, School of Agriculture, Suresh Gyan Vihar University, Jaipur-302 017, Rajasthan, India.

${ }^{2}$ Department of Agronomy, Faculty of Agriculture, Annamalai University, Annamalainagar-608 002, Tamil Nadu, India.
} 
Farm, Department of Agronomy, School of Agriculture, Suresh Gyanvihar University, Jaipur (Rajasthan). Climate of the region is sub-tropical and semi-arid climate with the monsoon commencing from July and withdrawing by September. For the intended study 8 treatments were tested under three replications by using randomized block design. The treatments consist of $\mathrm{T}_{1}$ control, $\mathrm{T}_{2} 1.0 \% \mathrm{FeSO}_{4}$ as foliar spray at $25 \mathrm{DAS}, \mathrm{T}_{3}: 25 \mathrm{~kg} \mathrm{~S} \mathrm{ha}^{-1}$ as $\mathrm{ZnSO}_{4}, \mathrm{~T}_{4} 25 \mathrm{~kg} \mathrm{~S} \mathrm{ha}^{-1}$ as SSP, $\mathrm{T}_{5} 25 \mathrm{~kg} \mathrm{~S} \mathrm{ha}^{-1}$ as $\mathrm{ZnSO}_{4}+1.0 \% \mathrm{FeSO}_{4}$ as foliar

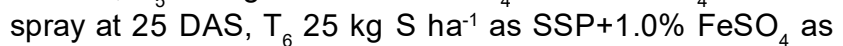
foliar spray at $25 \mathrm{DAS}, \mathrm{T}_{7} 12.5 \mathrm{~kg} \mathrm{~S}^{-1}$ as $\mathrm{ZnSO}_{4}+12.5 \mathrm{~kg}$ $\mathrm{S} \mathrm{ha}^{-1}$ as SSP and $\mathrm{T}_{8} 12.5 \mathrm{~kg} \mathrm{~S} \mathrm{ha}^{-1}$ as $\mathrm{ZnSO}_{4}+12.5 \mathrm{~kg} \mathrm{~S}$ $\mathrm{ha}^{-1}$ as SSP+1.0\% $\mathrm{FeSO}_{4}$ as foliar spray at $25 \mathrm{DAS}$. Nutrient management was done through SSP, $\mathrm{ZnSO}_{4}$ and $\mathrm{FeSO}_{4}$ to supply the required $\mathrm{S}, \mathrm{Fe}$ and other. Full dose of inorganic source $\mathrm{N}, 20 \mathrm{~kg} \mathrm{ha}^{-1}$ was applied in two spilt doses. The data on various growth and yield were recorded in different treatments. All the data were statistically analysed.

\section{RESULTS AND DISCUSSION Growth attributes}

Plant height, number of root nodules plant ${ }^{-1}$ and number of branches plant $^{-1}$ were significantly affected by various treatments (Table 1). The results revealed that treatment $\mathrm{T}_{8}$ $\left(12.5 \mathrm{~kg} \mathrm{~S} \mathrm{ha}^{-1}\right.$ as $\mathrm{ZnSO}_{4}+12.5 \mathrm{~kg} \mathrm{~S}^{-1}$ as SSP $+1.0 \%$ $\mathrm{FeSO}_{4}$ as foliar spray at $25 \mathrm{DAS}$ ) recorded significantly greater plant height $(54.81 \mathrm{~cm})$, number of root nodules plant ${ }^{-1}$ (73.82), dry weight plant ${ }^{-1}(21.54 \mathrm{gm})$ and number of branches plant $^{-1}(7.13)$ at 60 DAS. All growth qualities consistently increase following seeding of crop establishment till physiological maturity in all the treatments over the duration of inquiry. These findings are in accordance with the results reported by (Piri et al., 2012) and (Sahu et al., 2008).

\section{Grain yield}

The maximum grain yield $\left(7.90 \mathrm{q} \mathrm{ha}^{-1}\right)$ was achieved by the treatment $\mathrm{T}_{8}\left(12.5 \mathrm{~kg} \mathrm{~S} \mathrm{ha}^{-1}\right.$ as $\mathrm{ZnSO}_{4}+12.5 \mathrm{~kg} \mathrm{~S}^{-1}$ as $\mathrm{SSP}+1.0 \% \mathrm{FeSO}_{4}$ ) and it was $59.87 \%$ greater compared to the lowest grain yield $\left(4.73 \mathrm{q} \mathrm{ha}^{-1}\right)$ seen in treatment $\mathrm{T}_{1}$ (Control). It was followed by application of $\mathrm{ZnSO}_{4}+1.0 \%$ $\mathrm{FeSO}_{4}$ as foliar spray at 25 DAS $\left(\mathrm{T}_{5}\right)$ Table 2 . The results are in line with the study described by Khorgamy and Farin, (2009) and Valenciano et al., (2010), who claimed that the higher grain yield attained in green gram may be related to improved metabolic processes in plants owing to sulphur treatment using $\mathrm{ZnSO}_{4}$ and SSP. The iron in ferrous sulphate also assists in absorption of nutrients, which are believed

Table 1: Influence of sulphur and iron on growth attributes of green gram (Vigna radiata L.).

\begin{tabular}{|c|c|c|c|c|}
\hline Treatments & $\begin{array}{l}\text { Plant height } \\
\qquad(\mathrm{cm})\end{array}$ & $\begin{array}{l}\text { Number of root } \\
\text { nodules plant }{ }^{-1}\end{array}$ & $\begin{array}{l}\text { Dry weight } \\
\left(\text { g plant }^{-1}\right)\end{array}$ & $\begin{array}{l}\text { Number of } \\
\text { branches plant }^{-1}\end{array}$ \\
\hline Control & 42.91 & 51.98 & 14.38 & 4.67 \\
\hline $1 \% \mathrm{FeSO}_{4}$ as foliar spray at $25 \mathrm{DAS}$ & 45.10 & 54.66 & 16.11 & 5.80 \\
\hline $25 \mathrm{~kg} \mathrm{~S} \mathrm{ha}^{-1}$ as $\mathrm{ZnSO}_{4}$ & 49.51 & 60.08 & 16.45 & 6.07 \\
\hline $25 \mathrm{~kg} \mathrm{~S} \mathrm{ha}^{-1}$ as SSP & 47.68 & 55.68 & 16.23 & 5.92 \\
\hline $25 \mathrm{~kg} \mathrm{~S} \mathrm{ha}^{-1}$ as $\mathrm{ZnSO}_{4}+1 \% \mathrm{FeSO}_{4}$ as foliar spray at $25 \mathrm{DAS}$ & 52.48 & 72.77 & 20.63 & 6.47 \\
\hline $25 \mathrm{~kg} \mathrm{~S} \mathrm{ha}^{-1}$ as SSP $+1 \% \mathrm{FeSO}_{4}$ as foliar spray at $25 \mathrm{DAS}$ & 51.08 & 61.44 & 17.10 & 6.27 \\
\hline $12.5 \mathrm{~kg} \mathrm{~S} \mathrm{ha}^{-1}$ as $\mathrm{ZnSO}_{4}+12.5 \mathrm{~kg} \mathrm{~S} \mathrm{ha}^{-1}$ as SSP & 51.83 & 69.87 & 18.37 & 6.33 \\
\hline $\begin{array}{l}12.5 \mathrm{~kg} \mathrm{~S} \mathrm{ha}^{-1} \text { as } \mathrm{ZnSO}_{4} \mathrm{ha}^{-1}+12.5 \mathrm{~kg} \mathrm{~S} \mathrm{ha}^{-1} \text { as SSP }+1 \% \\
\mathrm{FeSO}_{4} \text { as foliar spray at } 25 \text { DAS }\end{array}$ & 54.81 & 73.82 & 23.54 & 7.13 \\
\hline F- test & $\mathrm{S}$ & $S$ & $S$ & $S$ \\
\hline S. Ed. $( \pm)$ & 2.47 & 3.47 & 0.93 & 0.35 \\
\hline C.D. $(P=0.05)$ & 5.29 & 7.44 & 2.00 & 0.78 \\
\hline
\end{tabular}

Table 2: Influence of sulphur and iron on yield of green gram.

\begin{tabular}{|c|c|c|}
\hline Treatments & Grain yield $\left(q\right.$ ha $\left.^{-1}\right)$ & Stover yield $\left(\mathrm{q} \mathrm{ha} \mathrm{a}^{-1}\right)$ \\
\hline Control & 4.73 & 5.88 \\
\hline $1 \% \mathrm{FeSO}_{4}$ as foliar spray at $25 \mathrm{DAS}$ & 5.43 & 6.53 \\
\hline $25 \mathrm{~kg} \mathrm{~S} \mathrm{ha}^{-1}$ as $\mathrm{ZnSO}_{4}$ & 6.45 & 6.97 \\
\hline $25 \mathrm{~kg} \mathrm{~S} \mathrm{ha}^{-1}$ as SSP & 5.47 & 6.86 \\
\hline $25 \mathrm{~kg} \mathrm{~S} \mathrm{ha}^{-1}$ as $\mathrm{ZnSO}_{4}+1 \% \mathrm{FeSO}_{4}$ as foliar spray at $25 \mathrm{DAS}$ & 7.79 & 7.72 \\
\hline $25 \mathrm{~kg} \mathrm{~S} \mathrm{ha}^{-1}$ as SSP $+1 \% \mathrm{FeSO}_{4}$ as foliar spray at $25 \mathrm{DAS}$ & 6.79 & 7.20 \\
\hline $12.5 \mathrm{~kg} \mathrm{~S} \mathrm{ha}^{-1}$ as $\mathrm{ZnSO}_{4}+12.5 \mathrm{~kg} \mathrm{~S} \mathrm{ha}^{-1}$ as SSP & 7.17 & 7.29 \\
\hline $12.5 \mathrm{~kg} \mathrm{~S} \mathrm{ha}^{-1}$ as $\mathrm{ZnSO}_{4} \mathrm{ha}^{-1}+12.5 \mathrm{~kg} \mathrm{~S} \mathrm{ha}^{-1}$ as SSP $+1 \%$ & 7.90 & 8.02 \\
\hline \multicolumn{3}{|l|}{$\mathrm{FeSO}_{4}$ as foliar spray at 25 DAS } \\
\hline F- test & S & S \\
\hline S. Ed. $( \pm)$ & 0.34 & 0.38 \\
\hline C.D. $(P=0.05)$ & 0.74 & 0.81 \\
\hline
\end{tabular}


to have an effective photosynthetic mechanism and be better prepared for efficient translocation of photosynthates from source to sink, subsequently leading in higher grain production (Singh et al., 1999).

\section{Stover yield}

The maximum stover yield (8.02 $\left.\mathrm{q} \mathrm{ha}^{-1}\right)$ was produced by application of $12.5 \mathrm{~kg} \mathrm{~S}^{-1}$ as $\mathrm{ZnSO}_{4}+12.5 \mathrm{~kg} \mathrm{~S} \mathrm{ha}^{-1}$ as $\mathrm{SSP}+1.0 \% \mathrm{FeSO}_{4}\left(\mathrm{~T}_{8}\right)$ and it was 73.31 per cent greater compared to the lowest stover yield (5.88 $\left.\mathrm{q} \mathrm{ha}^{-1}\right)$ seen in treatment $T_{1}$ (Control). It was followed by $T_{5}\left(25 \mathrm{~kg} \mathrm{~S} \mathrm{ha}^{-1}\right.$ as $\mathrm{ZnSO}_{4}+1.0 \% \mathrm{FeSO}_{4}$ as foliar spray at 25 DAS). According to Nadergoli et al., (2011), sulphur nutrition enhances cell multiplication, elongation, expansion and is known to impart a deep green colour to leaves due to better chlorophyll synthesis, which in turn increases the effective area for photosynthesis and thus, results in an increase in stover yield of a plant. In addition to sulphur, the availability of iron also helps in absorption of nutrients, which are expected to have an efficient photosynthetic mechanism and be better equipped for efficient translocation of photosynthates from source to sink, consequently resulting in increased stover yield (Singh et al., 1999).

\section{CONCLUSION}

The experiment "Performance of Green gram as Influenced by Sulphur and Iron Application" conducted during kharif season of 2018 concluded that application of $12.5 \mathrm{~kg} \mathrm{~S} \mathrm{ha}^{-1}$ as $\mathrm{ZnSO}_{4}+12.5 \mathrm{~kg} \mathrm{~S} \mathrm{ha}{ }^{-1}$ as SSP $+1 \% \mathrm{FeSO}_{4}$ as foliar spray at 25 DAS registered highest growth and yield parameters observed, viz., plant height $(54.81 \mathrm{~cm})$, number of root nodules plant ${ }^{-1}$ (73.82), dry weight plant ${ }^{-1}(23.54 \mathrm{~g})$, number of branches plant ${ }^{-1}(7.13)$ grain yield $\left(7.90 \mathrm{q} \mathrm{ha}^{-1}\right)$ and stover yield (8.02) compared with the other treatments.

\section{REFERENCES}

Anonymous (2018). Agriculture Statistics at a Glance. Directorate of Economics and Statistics, Ministry of Agri. and FW, New Delhi.
Bhattacharjee, A., Lehtinen, M.J., Kajander, T., Goldman, A. and Jokiranta, T.S. (2013). Both domin 19 and domin 20 of factor $\mathrm{H}$ are involved in binding to complement $\mathrm{C} 3 \mathrm{~b}$ and C3d. Mol Immunol. 47: 1686-1691.

Goos, R.J. and Johnson, B.E. (2000). A comparsion of three methods for reducing iron-deficiency chlorosis in soybean. Agron. J. 92: 1135-1139.

Khorgamy, A. and Farina, A. (2009). Effect of phosphorus and zinc fertilization on yield and yield components of chick pea cultivars. Afr. Crop Sci. Conf Proceedings. 9: 205-208.

Nadergoli, M.S., Yarnia, M. and Khoei, F.R. (2011). Effect of zinc and manganese and their application method on yield and yield components of common bean (Phaseolus vulgaris L.). Middle-East J. Sci. Res. 8: 859-865.

Piri, I., Nik, M.M., Tavassoil, A., Rastegaripour, F. and Babaeian, M. (2012). Effect of Irrigation frequency and application levels of sulphur fertilizer on water-use efficiency and yield of Indian mustard (Brassica juncea). Afr. J. Biotechnol. 10: $11459-11467$.

Sahu, S., Lidder, R.S. and Singh, P.K. (2008). Effect of micronutrients and bio fertilizers on growth, yield and nutrients uptake by Chickpea (Cicer arietinum L.) in vertisol of Madhya Pradesh. Adv. PI. Sci. 21(3): 501-503.

Sawan, Z.M., Hafez, S.A. and Basyony, A.E. (2001). Effect of phosphorus fertilization and foliar application of chelated zinc and calcium on seed, protein and oil yields and oil properties of cotton. J. Agric. Sci. 136: 191-198.

Singh, A.L., Joshi, Y.C., Chaudhari, V. and Zala, P.V. (1999). Effect of different sources of Iron and Sulphur on leaf chlorosis, nutrient uptake and yield of groundnut. Ferti. Res. 24: 85.

Usman, F., Hassan, A. and Ahmad, A. (2007). Arterial ischemic stroke with protein deficiency in Pakistan. Raw Medi. J. 32: 205-207.

Valenciano, J.B., Boto, J.A. and Marcelo, V. (2010). Response of chick pea (Cicer arietinum L.) yield to zinc, boron and molybdenum application under pot conditions. Span. J. Agric. Res. 8: 797-80. 